\title{
The effect of feed on offer on the nutritive value of annual pastures in summer
}

\author{
YJ Ru, JA Fortune \\ Department of Agronomy and Farming Systems, Roseworthy Campus, The University of Adelaide, \\ Roseworthy, South Australia 5371, Australia
}

In Mediterranean environments, the seasonal pasture supply is characterised by high quality, low quantity in winter and low quality and quantity in summer. The poor quality of pasture in summer is the result of a combination of relative maturity of the plants when lack of moisture induces senescence, and prior accumulation of dead material in swards due to lax grazing. This experiment was designed to study the effect of feed on offer (FOO) in the grazing season on the nutritive value of pasture in summer.

At Mt Barker Research Station in Western Australia, an area was fenced into individual 1 hectare plots. Sheep were introduced to the plots in July and continuously stocked to maintain FOO in the areas used for this work throughout Spring at about 1000, 1500, 2000 and $2500 \mathrm{~kg} / \mathrm{ha}$ with one set stock treatment ( 8 sheep/ha, FOO $>5000 \mathrm{~kg} / \mathrm{ha}$ ) which was consistent with local farm practice. Each treatment had 3 replicates. The target FOO were maintained by adding or removing sheep as required to match pasture growth until late Spring. In each plot, 6 quadrats $\left(0.1 \mathrm{~m}^{2}\right)$ of pasture were taken by cutting herbage above ground level in December 1992 and February 1993, then bulked and freeze dried. The dry matter digestibility (DMD) was estimated by pepsin-cellulose method, and crude protein (CP) was analysed using Kjedahl method.
The result showed that DMD and CP of the herbage was higher in December than in February $(P<0.05)$. DMD of herbage $(Y)$ in both December and February was negatively related to FOO $(X)$, with the regressions being $Y=48.509-0.002 X\left(R^{2}=0.45\right)$ and $Y=$ $30.474-0.001 \times\left(\mathrm{R}^{2}=0.40\right)$ respectively. $\mathrm{CP}$ was negatively related to FOO in December while no correlation was found in February. The effect of hard grazing persisted through summer with the DMD in February only declining to that found in the lax grazed plots in December.

This experiment demonstrated that the quality of pasture in summer was significantly influenced by grazing intensity during growing season. Pastures maintained under lax grazing contained a large amount of old and dead material which was more mature, and low in $\mathrm{CP}$ content, and would require more time to be digested as Buxton reported (1989, Proc XVI Intern Grassl Congr, 917-918). Pastures more closely grazed in Spring (low FOO) had more young branches and leaves which was reflected in higher quality.

In conclusion, grazing intensity can be used as a management strategy to maintain optimum FOO to enable pasture to reach its highest growth rate, and improve nutritive value in summer.

\begin{tabular}{llcccr}
\hline & Hard grazed & & $\rightarrow$ & & Lax grazed \\
FOO $(\mathrm{kg} / \mathrm{ha})$ & 1000 & 1500 & 2000 & 2500 & $>5000$ \\
$\begin{array}{l}\text { December, } 1992 \\
\text { DMD }(\%)\end{array}$ & 44.5 & 40.3 & 46.3 & 39.0 & 30.1 \\
CP $(\%)$ & 10.62 & 10.09 & 10.15 & 9.05 & 8.44 \\
February, 1993 & & & & & \\
DMD (\%) & 30.8 & 29.1 & 29.6 & 28.1 & 25.9 \\
CP $(\%)$ & 7.00 & 8.25 & 7.20 & 7.19 & 6.96 \\
\hline
\end{tabular}

